\title{
The pH Value, Total Dissolved Solid and Sensory Profile of Silky Pudding with "secang" Wood Extract (Caesalpinia sappan L.)
}

\section{Suci Rahayu, Alsuhendra, and Ridawati}

Faculty of Engineering, State University of Jakarta, Kampus A UNJ Gd. H. Lt.2, Jalan Rawamangun Muka Jakarta 13220

\section{Abstract}

The $\mathrm{pH}$ value, total dissolved solids (TDS), and sensory profile of silky pudding with "secang" wood extract were studied. The dessert added with "secang" wood extract is known as a functional food. "Secang" wood is one of the plant material that is used as a natural dye for food, drinks, and a potential source of natural antioxidants. This study aimed to determine the effect of adding "secang" wood extract as much

Corresponding Author: Suci Rahayu

alsuhendra@gmail.com

Received: 11 January 2019

Accepted: 14 February 2019

Published: 25 March 2019

Publishing services provided by Knowledge E

(c) Suci Rahayu et al. This article is distributed under the terms of the Creative Commons

Attribution License, which permits unrestricted use and redistribution provided that the original author and source are credited.

Selection and Peer-review under the responsibility of the 3rd ICTVET 2018 Conference Committee.

\section{G OPEN ACCESS} as $20 \%(\mathrm{~V} / \mathrm{V})$ and $40 \%(\mathrm{~V} / \mathrm{V})$ on $\mathrm{pH}$ value, TDS, and sensory profile of silky pudding. Spider chart and two-way ANOVA analyzed the sensory profile of the silky pudding with added "secang" wood extract. Analyses reveal that the $\mathrm{pH}$ value range was $6.74-6.82$ and the TDS range was $13.0-13.2^{\circ} B$ Brix. The extract used in this study had influences on the profile sensory of the color, taste, aroma, and texture of silky pudding.

Keywords: "secang" wood, silky pudding, sensory profile

\section{Introduction}

Pudding is one type of cold dessert because it made undergoes a cooling process. This product is favored by various age groups starting from teenagers to adults and has developed many variations. One of the pudding products that are popular is silky pudding. Silky pudding is a pudding product which has a soft and silky-like texture.

Silky pudding is acceptable by Indonesian tongue and processed into attractive products with a variety of exciting flavors, or functional ingredients likes secang wood extract. The raw material of silky pudding is fresh milk, sugar, agar, and glucomannan. The production process of the silky pudding is the same as the production process of other pudding in general.

The main ingredient of the silky pudding is milk, so it requires special treatment such as storage in a temperature refrigerator below $4^{\circ} \mathrm{C}$. The products must be stored in low temperatures because milk as the main ingredient can become a medium of growth 
that is good for dairy-destroying bacteria. Some bacteria that often contaminate milk are coliform bacteria, lactic acid bacteria, and others spoilage bacteria.

Recent, silky pudding not only variates sweet taste but also variates beauty in presentation, color, and another benefit so that consumers can serve with delicious food and beautiful appearance. One of the natural coloring ingredients that are often used in food processing, especially pastry and traditional drinks is "secang" extract.

"Secang" wood is used as a raw material in traditional medicines, traditional foods, and healthy drinks. The specific component of "secang" wood, brazilin, an isoflavone, is known to have antioxidant and antibacterial activities. The use of natural dyes for food products has some advantages because it produces a unique exotic color with exclusive imaging and is body friendly due to the easily degraded in metabolism. "Secang" wood pigment obtained by extraction method. The extraction method was carried out by maceration using hot water solvents [1].

Meanwhile "secang" wood is very potential to be used as a source of natural red dye because of the amount of the "secang" wood which is very abundant in Indonesia, and it has not been utilized optimally. The negative side of "secang" wood is its instability of the Brazilin, a compound contained within the "secang" wood extract itself. It has been reported that the color of "secang" wood extract was influenced by $\mathrm{pH}$ solution [2]. In acid solution, "secang" liquid show yellow-orange, red in neutral solution, and purple-violet in the base solution. Brazilin is a dahlia yellow-colored compound while brazilin is a reddish colored compound. The change-over of brazilin into brazilin is due to the delocalization of the electrons because of the presence of carbonyl groups as a result of the oxidation process of brazilin.

This study aimed to determine the effect of addition " secang" wood extract as much as $20 \%(\mathrm{v} / \mathrm{v})$ and $40 \%(\mathrm{v} / \mathrm{v})$ on $\mathrm{pH}$ value, TDS of silky pudding and sensory profile.

\section{Methodology}

\subsection{Materials}

The "secang" wood used in this research was obtained from the Kramat Jati Market, East Jakarta. Sweet Pasteurized Fresh Milk with vanilla flavor as the primary materials in the silky pudding and others materials likes agar, glucomannans, salt, and sugar were obtained from Market in Rawamangun, East Jakarta. The Fe solution, consisting of ferrous sulfate $\left(\mathrm{FeSO}_{4}\right)$ 2,4 $\mathrm{mg} / \mathrm{kg}$ was prepared from $\mathrm{FeSO}_{4}$ (Merck). 


\subsection{Methods}

This research was conducted in the Analysis and Food Engineering Laboratory, Faculty of Engineering, State University of Jakarta. The extraction process was done under optimum condition based on the previous research by modification [3]. This research conducted using water as solvent, $100^{\circ} \mathrm{C}$ temperature, and 60 minutes of the extraction time was kept in $60^{\circ} \mathrm{C}$. However, the ratio used in this research was $50 \mathrm{~g}: 500 \mathrm{~mL}$ of the weight of the "secang" wood to the volume of water as a solvent. It is intended to obtain the extracts that are suitable for the silky pudding recipe. All dry ingredients (6\% sugar, $0,2 \%$ agar, $0,2 \%$ glucomannan, and $0,1 \%$ salt were mixed well. Furthermore, the dry ingredients were dissolved into liquid milk while heated to a temperature of $70 \circ \mathrm{C}$. The solution of milk was fortified with 2,4 ppm iron and $48 \mathrm{ppm}$ ascorbic acid; then it was divided into three part. The first part (control) was added with water; the second part was the addition of $20 \%$ "secang" wood extract, the third part was the addition of $40 \%$ "secang" wood extract. All samples were left at $4^{\circ} \mathrm{C}$ for 3 hours. After setting, samples were analyzed. The $\mathrm{pH}$ value was quickly determined by portable $\mathrm{pH}$ meter (Extech) and TDS by hand-held refractometer $\mathrm{N}-1 \alpha$ (Atago), respectively. The sensory profile was determined as a result of discussions by seven trained panelists. Thirty five (35) consumers have assessed the effect of addition "secang" wood extract to sensory profile of silky pudding. A spider chart can graphically present the attribute of a sensory profile of the silky pudding with "secang" wood extract.

\section{Results and Discussion}

This study used "secang" wood obtained from Kramat Jati Market. It is clean, and there was no contamination of objects. It first cleaned and washed which aims to reduce the contaminant in the surface to extend the shelf life of the product, and then the process of making an extract by maceration method thus obtained extracts of "secang" wood. The extract sampled to know the $\mathrm{pH}$ value and TDS of the extract.

The "secang" wood extract gave a red-orange color for neutral $\mathrm{pH}$ condition $\mathrm{pH}$ extract $6,74 \pm 0,025)$. The color of "secang" wood extraction process and after $60 \mathrm{~min}$, was showed in Figure 1. This extract has TDS $0,18+0,027^{\circ} \mathrm{bx}$. This research used pure water $\left(0^{\circ} \mathrm{Brix}\right)$ as a solvent that often called the universal solvent. It is tasteless, colorless, and odorless.

Total dissolved solids is a measure of the dissolved combined content of all inorganic and organic substances contained in a liquid in molecular, ionized or microgranular 
suspended form. Total dissolved solids refer to any minerals, salts, metals, cations or anions dissolved in water. Total dissolved solids comprise inorganic salts (principally calcium, magnesium, potassium, sodium, bicarbonates, chlorides, and sulfates) and some small amounts of organic matter that dissolved in water.

A number of organic compounds are reported by Youstiana and Suhartono (2016), that "secang" wood has a component of a chemical compound essential oils, flavonoids, benzopyran, saponin, brazilin, cisalpine S, cisalpine P, sapanon A, sapanon B. There are types of flavonoids flavones, flavanols and flavanols on extracts of "secang" wood that has been resulted from maceration method and infusion method. Flavonoid content test results showed that the levels of flavonoids in extracts of "secang" wood that has been resulted from the maceration method and infusion methods were $0.0539 \%$ and $0.1902 \%$, respectively.

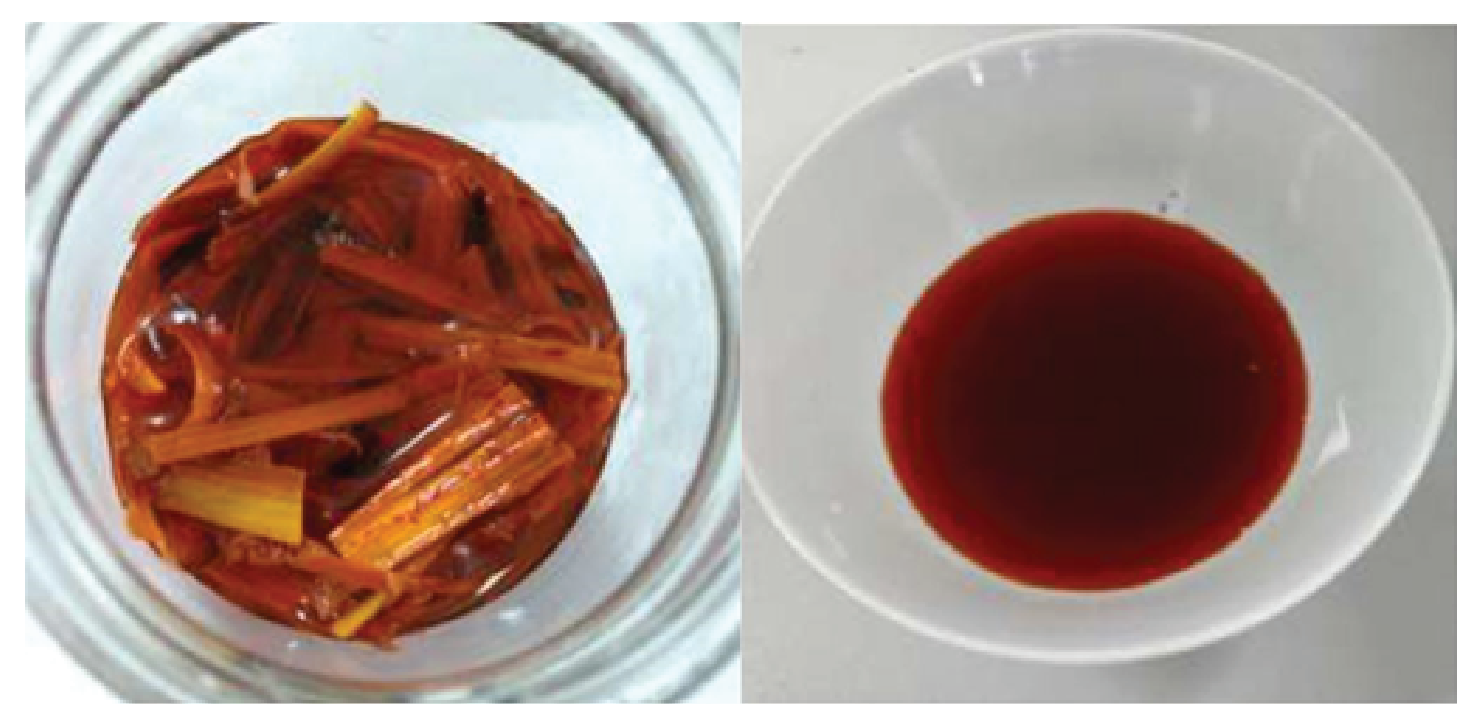

Figure 1: "Secang" wood in water (extraction process in water bath $60^{\circ} \mathrm{C}, 60 \mathrm{~min}$ (a) and "secang" wood extract after filtration (b)).

The process of making silky pudding in this study used the standard method of mixing and heating all the ingredients until dissolved. This silky pudding recipe was fortified with 2,4 ppm iron and $48 \mathrm{ppm}$ ascorbic acid. It was divided into three part. The first part (control) was added with drinking pure water, the other parts were added with $20 \%$ and $40 \%$ "secang" wood extract. After setting in refrigeration temperature $4^{\circ} \mathrm{C}$ for 3 hours, the $\mathrm{pH}$.

The $\mathrm{pH}$ value and TDS of the samples were analyzed. The $\mathrm{pH}$ value of the silky pudding averages was $6,79+0,03$. The conclusions of the two way ANOVA with replication, the $p$-value (treatment) $=0,525>0,05=\alpha$, it can't reject the null hypothesis, and so conclude (with 95\% confidence) that there are no significant differences of $\mathrm{pH}$ value between control, the treatment $20 \%$, and $40 \%$ "secang" wood extract. The 
TDS of the silky pudding averages were $13.12+0,03^{\circ} \mathrm{bx}$. Some conclusions from the two way ANOVA with replication, the $p$-value (treatment) $=0,868>0,05=\alpha$, it can't reject the null hypothesis, and so conclude (with 95\% confidence) that there are no significant differences of total dissolved solid between control, the treatment $20 \%$, and $40 \%$ "secang" wood extract. The "secang" wood extract in silky pudding caused the change of appearance of silky pudding (Figure 2).

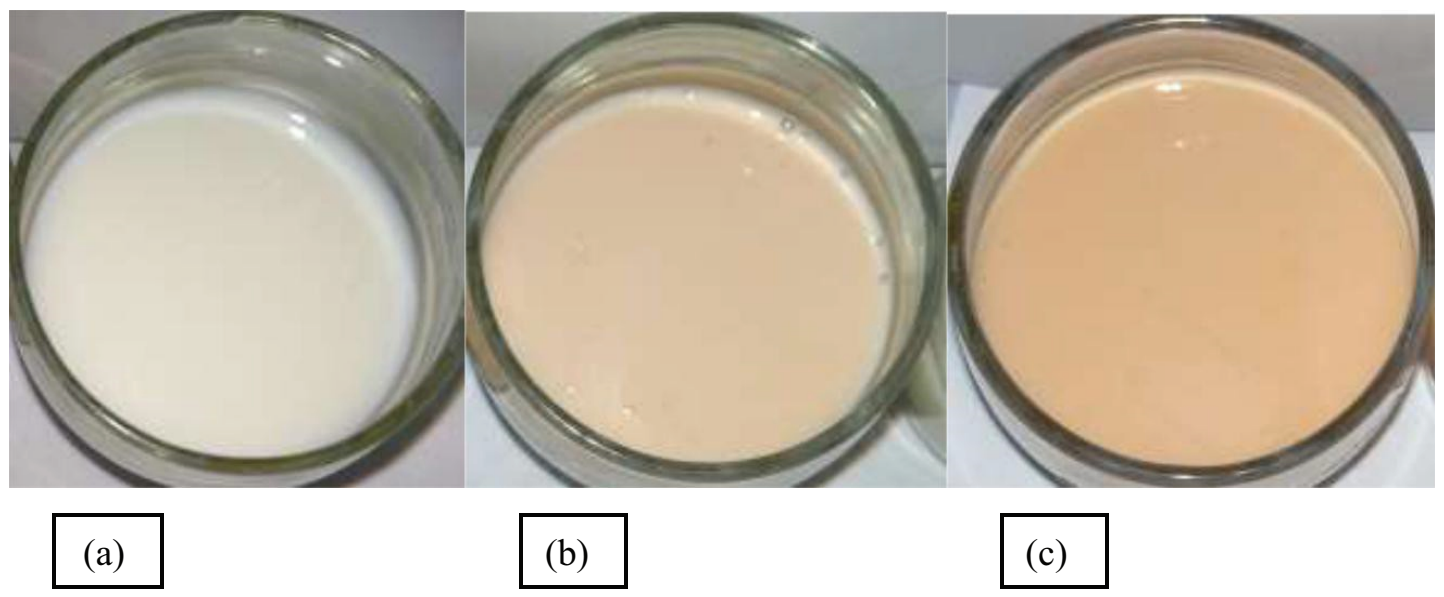

Figure 2: The silky pudding after refrigerating until it is chilled through a good three hours. (a) Control, (b) addition $20 \%$, and (c) addition $40 \%$ of "secang" wood extract (v/v).

This research presents the silky pudding 's sensory profile analysis results, carried out on three different products. The first product was control, its silky pudding without the addition of "secang" wood extract. The second product was silky pudding with the addition of "secang" wood extract $20 \%$; the third product was silky pudding with the addition of "secang" wood extract $40 \%$. The sweet pasteurized fresh milk as the main ingredient of silky pudding had TDS $12,2+0,15^{\circ} \mathrm{bx}$. It contains sugar, calcium, mineral components, vitamins D, A and some of vitamin B group. It supplies our body with proteins, the basic building blocks of cells and tissues, as well as carbohydrates which provide energy.

The sensory profile was determined as a result of discussions and agreed by consensus by seven trained panelists, working under the direction of a group leader. The results of the sensory profile were called a quantitative descriptive analysis (Quantitative Descriptive Analysis - QDA) and generally accepted as the basic version of the method of sensory descriptive analysis. The QDA method is widely used by companies to develop new products and to compare their products with the competition [4]. Its methods are used to keep track of sensory changes in the technology process, and many other purposes like to obtain the assessment of consumer preferences and to analyze the changes in sensory quality under the influence of various factors. The 
addition of "secang" wood extract in the silky pudding that had been fortified with iron and ascorbic acid was thought to be influential to the sensory profile oh silky pudding.

Trained panelists were selected based on their level of knowledge and sensitivity after going through several criteria, likes the knowledge of the product (silky pudding with "secang" wood extract and the ability to differentiate (sensory differentiation, ability to detect small differences). The first step was to create a set of descriptors (characteristics) relating to the silky pudding with "secang" wood extract, individually. All the evaluation were performed by the selected group of carefully chosen panelists [5]. During training, test products are served as illustrative stimuli for the consensus language development. The panel leader works as a communication facilitator without involvement and interference with panel discussions. The references can be the seed for generating the sensory terminologies, especially when panelists are confused and disagree with each other on some sensory attributes during training sessions.

The 5 points hedonic scale was applied in the process of assessment, allowing to obtain an average note of desirability of examined features, shown in Figure 3. The results of taste, flavor, color and texture desirability test fully confirmed the conclusions of the preference ranking. This assessment aimed to determine the sensory taste profile of the silky pudding treatment compare to control product. The aspect of the sensory profile was the sweetness, taste of milk, color, the flavor of milk, the flavor of "secang," flavor of vanilla, and texture, with five scales. The scale of sweetness was started from very sweet, sweet, sweeties, not sweet, not very sweet. The scale of color was started from orange, light, peach, yellowish orange and milk white, with the rank of scale 5 to 1 , respectively.

The taste of milk, the flavor of milk, the flavor of "secang," the flavor of vanilla, had the scale from very strong to very weak. The aspect of texture was very soft, soft, a bit soft, rough and sandiness.

The results of the effect of addition "secang" wood extract to sensory profile of silky pudding, shown in Figure 3. The sensory aspect assessment was $p$-value $1.886>0.05$ so that there was no influence of every aspect of the assessment of the panelist's assessment results. The addition of "secang" extract was $p$-value $0.003<0.05$ so that there was a difference in the addition of "secang" extract to the panelists' assessment results from each aspect compared to the control (without the addition of "secang" extract). 


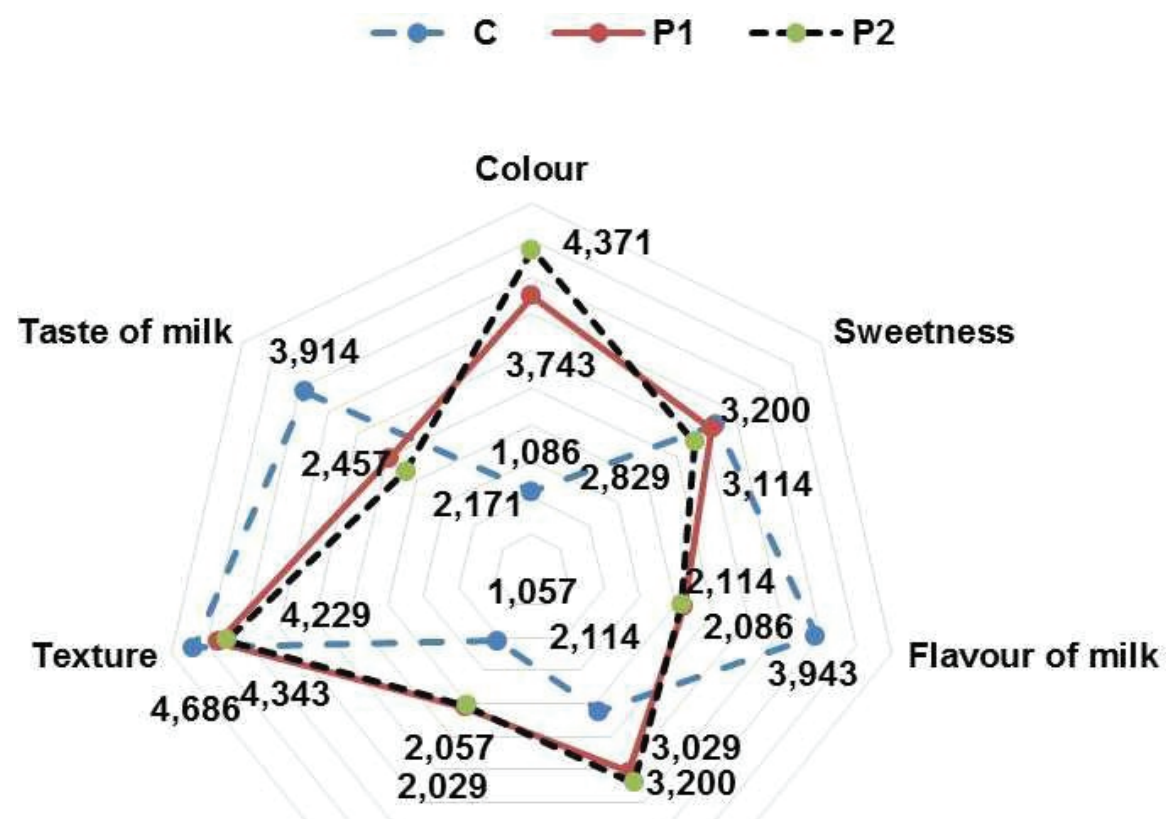

Flavour of secang

Flavour of vanilla

Figure 3: The results of the effect of addition "secang" wood extract to sensory profile of silky pudding.

\section{Conclusion}

There are no significant differences between the $\mathrm{pH}$ value and total dissolved solid between control, the treatment 20\%, and $40 \%$ "secang" wood extract. These were presented results of the sensory profile analysis of taste in a trained panelist of silky pudding the sweetness, taste of milk, color, the flavor of milk, the flavor of "secang," the flavor of vanilla, and texture, with five scales. The scale of sweetness was started from very sweet, sweet, sweeties, not sweet, not very sweet. The scale of color was started from orange, orange white, peach, yellowish orange and milk white, with the rank of scale 5 to 1, respectively. The taste of milk, the flavor of milk, the flavor of "secang," the flavor of vanilla, had the scale from very strong to very weak. The aspect of texture was very soft, soft, a bit soft, rough and sandiness. There was no influence on every aspect of the assessment of the panelist's assessment results. There was a difference in the addition of "secang" extract to the panelists' assessment results from each aspect compared to the control (without the addition of "secang" extract).

\section{Funding}

This work was supported by the Rector of the State University of Jakarta and the Dean of the Faculty of Engineering, State University of Jakarta. 


\section{Acknowledgment}

The authors would like to thank the team of researchers. This research could not have been possible without the work of innovative and high dedication to developing science. The authors are very much thankful to the Dean of the Faculty of Engineering for providing laboratory facilities and funding this research.

\section{Conflict of Interest}

The authors have no conflict of interest to declare.

\section{References}

[1] Lousiana Dwi Rusita and Suhartono. 2016. Flavonoids content in extracts "secang" (Caesalpinia Sappan L.) maceration method infundation analysis and visibleultraviolet spectrophotometer. International Journal of Medical Research \& Health Sciences (5), 4:176-181 176.

[2] Saraswati, I. 2016. pH Value Affecting to the Colour of Kayu "secang" (Caesalpinia Sappan L) as a New Natural Indicator. Media Muda. Faculty of Medicine of Diponegoro University. Stone H., Sidel JL. 2004. Sensory Evaluation Practices. 3rd ed. San Diego, CA. Elsevier Academic Press.

[3] Ulma Z, Rahayuningsih E, Wahyuningsih, T.D. 2017. Methylation of Brazilin on "secang" (Caesalpinia sappan Linn) Wood Extract to Maintain Color Stability to the Changes of $\mathrm{pH}$. International Conference on Chemistry and Material Science (IC2MS). IOP Publishing.

[4] Jerzy Szakiel and Artur Wolak. 2011. Sensory Profile Analysis of Dairy Products Exemplified by Kefirs. Biblioteka Nauki: nr 214: 235-244. The Cracow University of Economics.

[5] Meilgaard M., Civille GV., Carr BT. 2007. Sensory Evaluation Techniques. 4th ed. Boca Raton Press. 